\title{
Effectivity and safety of mahkota dewa fruit extract compared to meloxicam (phaleria macrocarpa fructus) on osteoarthritis
}

\author{
AR Rahmadi', S Dewi', A Nawawi², IK Adnyana², R Gunadi
}

${ }^{1}$ Department of Internal Medicine, Padjadjaran University, Hasan Sadikin Hospital ${ }^{2}$ School of Pharmacy Institute Technology Bandung

\begin{abstract}
Background: Osteoarthritis $(\mathrm{OA})$ is the most common musculoskeletal disease. World Health Organization (WHO) estimates that 10\% of the aged over 60 year population have this disease. The aim of OA treatment is to reduce pain, which is the most OA patients chief complaint. People in Indonesia are very interested in use of herbal therapies from original traditional plant to treat pain now, one of the traditional plants that are known have a benefit is Phaleria macrocarpa or Mahkota Dewa fruit. Phaleria macrocarpa has been shown to decrease the degree of inflammation of $\mathrm{OA}$ animal model experiments. In order to know what is the effect of this fruit extract to reduce degrees of pain and change the levels of IL-1, IL-6, TNF- $\alpha$ in the blood as the marker of inflammation of patients with knee $0 \mathrm{~A}$, and what is the effects to liver, kidney and haematology in the Indonesian population has not been investigated.
\end{abstract}

Methods: The research method is an experimental study and the research design is PROBE (Prospective Randomized Open End Blinded Evaluation), to evaluate the efficacy of the extract Mahkota Dewa fruit (Phaleria macrocarpa fructus) $330 \mathrm{mg}$ (Super Mahkota POM TR 053345 491) compared to meloxicam $7.5 \mathrm{mg}$ in patients with knee osteoarthritis. The study population was outpatients with knee OA at Rheumatology Clinic Dr Hasan Sadikin Hospital Bandung. Patients are given Phaleria macrocarpa $330 \mathrm{mg}$ or meloxicam $7.5 \mathrm{mg}$ once a day for 14 days. Observations were made to evaluate the degree of pain as measured by VAS and Lequesne index at day 0 , day 14 and measured again at day 28 , after they are not taking the extract anymore.

Results: Phaleria macrocarpa $330 \mathrm{mg}$ is equal to meloxicam $7.5 \mathrm{mg}$ in reducing the degree of pain as measured by VAS $(p=0.78)$ and the Lequesne index $(p=0.51)$. Our finding, there is no effect of decreasing the proinflammatory cytokine IL-1 ( $p=0.72)$, IL-6 $(p=0.53)$ and TNF- $\alpha(p=0.07)$ in the blood of both groups. Safety analysis shown that this extract is safe for consumption.

Conclusions: Phaleria macrocarpa $330 \mathrm{mg}$ equal to meloxicam $7.5 \mathrm{mg}$ in reducing the degree of pain however there is no effect on reducing proinflammatory cytokines in the blood of OA patients who had received therapy for 14 days in both groups. There is no adverse effects found on hematological, liver function and kidney function after consumption this plant's fruit extract. Keywords: osteoarthritis, mahkota dewa, phaleria macrocarpa.

Osteoarthritis (OA) is the most common musculoskeletal disease, where the pathogenesis is still not known well, but it is currently developing several hypotheses and theories are still debatable., ${ }^{1,2}$ OA formerly regarded as a non-inflammatory diseases caused by degenerative disease due to increasing age, but along with the development of research, it is known that OA is fairly complex disease, multifactorial causes, although the etiology is not well known, and the disease also occurs as a result of not severe acute inflammation. ${ }^{2}$ World Health Organization (WHO) estimates that $10 \%$ of the entire population over the age of 60 years suffer from this disease. OA and other rheumatic diseases affecting more than 43 million people in the United States in 2020 and is expected to reach to 60 million patients. ${ }^{3,4}$ The study in UK shows the OA incidence is $25 \%$ per year, with the prevalence of disability due to knee OA is $10 \%$ and the severe disability as much as $5 \% .^{5}$

$\mathrm{OA}$ is also causing high socio-economic impact, both in developed countries as well as in developing countries, including Indonesia. ${ }^{6,7}, \mathrm{It}$ is estimated that one to two million elderly people in Indonesia suffer from disability due to OA. In the next century, the challenge of the OA impact will be even greater in elderly population. ${ }^{9,10}$

Currently, OA is characterized by the damage to the joint cartilage gradually accompanied by the presence of joint inflammation. OA can affect any joint, but is more common in the knees, hips, spine and hands. ${ }^{2,11-13}$ Pain is the main complaint of patients with osteoarthritis. Therefore, in general, the aims to the treatment of OA are to reduce pain, to prevent deformity, to improve quality of life, and to provide knowledge to the people about the disease.

The pathogenesis of $\mathrm{OA}$ is not only a degenerative process, but also inflammation. Joint pain, tenderness, limited range of motion, crepitus and swollen, increase intra-articular pressure, 
changes in the structure of the joints and tissue debris cause inflammation of the synovial membrane, capsule, tendon, and bursa. Proinflammatory cytokines such as IL-1, IL-6 and TNF- $\alpha$ are found to be high in the synovial fluid of the knee OA patients. ${ }^{11,12,17,18}$

Pharmacologic therapy in knee OA is divided into two main outcomes. The first, to reduce pain by analgesics, nonsteroidal anti-inflammatory drugs (NSAIDs), intra-articular injections, steroids, hyaluronan acid. The second, drugs used to inhibit the progression of OA are Modifying Osteoarthritis Drugs (DMOADs). DMOADs work by maintaining structural balance and stimulate the growth of cartilage cells of cartilage. Several studies have found that these drugs also have antiinflammatory effects. . $^{11,12,14,16}$

Nowadays people are very interested in the use of herbal therapies derived from traditional plant. One of the traditional plants that are known to have benefits is Phaleria macrocarpa or mahkota dewa. ${ }^{19,20}$

Mahkota Dewa fruit extract (Phaleria macrocarpa fructus) has been shown to reduce the degree of OA in animals, because the structure of the active substance similar to ketoprofen. Mahkota Dewa fruit ethanol extract with the doses of 15; 22.5 ; and $30 \mathrm{mg} / \mathrm{kg}$ bw mice can reduce levels of interleukin$1 \beta$ and TNF- $\alpha$ serum -induced arthritis in mice kolagen. ${ }^{21,22}$ Study in human clinical trials have not been conducted, but as a process of standardization we get a dose of Mahkota Dewa fruit extract $330 \mathrm{mg}$ per day according to animal study doses.

\section{Methods}

The study design was an experimental research, the research design is Prospective Randomized Open-label Blinded at End Experimental (PROBE) to evaluate the efficacy of the mahkota dewa fruit extract 330mg (Super Mahkota, POM: TR 053345491 ) compared to $7.5 \mathrm{mg}$ meloxicam as control group in patients with osteoarthritis.

The study population was patients with $\mathrm{OA}$ at the Rheumatology Outpatient Clinic in Dr. Hasan Sadikin General Hospital who live around Bandung city. Then sample was taken by simple random sampling methods to establish a research subject.

Inclusion criteria are patients with knee OA based on the consensus of the Indonesian Rheumatology Association (IRA), based on clinical (joint pain) and radiological (osteophytes), with at least 1 of the following 3 criteria: stiffness less than 30 minutes, age more than 50 years, crepitus on active joint motion; patients with OA pain intensity scores 2-7 according to Visual Analogue Scale (VAS). Exclusion criteria are there are other comorbidities: COPD, cardiac decompensation, walking disability was not caused by knee OA; undergoing medical rehabilitation; history of allergy to meloxicam or mahkota dewa; AST and ALT exceed twice the upper limit, normal creatinine $>1.1 \mathrm{mg} / \mathrm{dl}$; using NSAIDs and oral or steroid injection 2 weeks or 3 months before the study.

Visual Analogue Scale (VAS) questionnaire is the most easy tool to be used by interviewer to determine the degree of pain that experienced by OA patients in numbers. Lequesne index for knee OA, also known as (Index of severity for knee OA), was originally developed in French and also in other languages such as German, Korea and Singapore. This index has been studied can be used in Asia and has been proven valid in Southeast Asian populations. This index consists of 11 questions divided into three sections, five questions relating to pain, two questions about distance running, and four questions about the ability of daily activity or quality of life. ${ }^{47}$

Radiological examination is sufficient to support the diagnosis, and also the degree of OA can be classified based on the radiological features. Semi-quantitative assessment done by Kellgren-Lawrence radiographic criteria and Osteoarthritis Research Society International (OARSI). ${ }^{44}$

Test material in this study is the mahkota dewa fruit extracts that have been carried out which one of them is the standardization of assay in accordance with the applicable regulations in Indonesia. This herbal remedy has been registered, with the trademark "Super Mahkota", which is registered under number: POM TR 053345 491, in the form of capsules containing $330 \mathrm{mg}$ of extract Phaleria macrocarpa each capsule. ${ }^{23,24}$

Patients treated by Mahkota Dewa fruit extract capsules 330 $\mathrm{mg}$ once a day for 14 days, in the treatment group and $7.5 \mathrm{mg}$ meloxicam once a day in the control group. Observations were made of the pain degree as measured by VAS and Lequesne index, which was performed before and after administration of Mahkota Dewa fruit extract. If the patients experienced pain during administration of the test material (VAS > 7), then they can be given an additional $500 \mathrm{mg}$ paracetamol orally at the beginning to $4000 \mathrm{mg}$ per day orally (rescue medication).

On day 1 and 14, blood samples were taken to measure the levels of IL-1, IL- 6 and TNF- $\alpha$. VAS and Lequesne index measured on day 14 and 28. Liver function measured with AST and ALT examination, renal function examination with ureum and creatinine, hematology examination with hemoglobin, leukocyte count, platelet count.

Kolmogorov-Smirnov test of Goodness of Fit performed to determine the normality of the distribution of the data. Statistical analysis done by $t$ test for data ratio or interval scale who normally distributed. To compare the data pairs in the experimental group used the Wilcoxon $\mathrm{Z}$ test. Level of significance is determined by the value of $p<0.05$.

\section{Results}

This study subjects were 42 patients. Six subjects were excluded from this study, because one person has other diseases like gout arthritis, one person does not follow the rules of taking the medication and four patients had dropped out.

Of the 36 patients who completed the study 19 patients had Mahkota Dewa fruit extract $330 \mathrm{mg}$ in each capsules and 17 patients had Meloxicam $7.5 \mathrm{mg}$. Average age of knee OA patients was 59.1 years old. Most of the study subjects were women (85.7\%), aged between 45 to 69 years old. The severity of radiological OA mostly located in the first degree (45.2\%) and second degree (42.9\%). 
Table 1 Characteristics of $\mathrm{OA}$ patient according to group of treatment

\begin{tabular}{|c|c|c|c|}
\hline \multirow[t]{2}{*}{ Variable } & \multicolumn{2}{|c|}{$\begin{array}{l}\text { Treatment Group } \\
\text { Mean (SD)/N(\%) }\end{array}$} & \multirow[t]{2}{*}{$P$ value } \\
\hline & $\begin{array}{l}\text { Phaleria Macro- } \\
\text { carpa } 330 \text { mg }\end{array}$ & $\begin{array}{l}\text { Control } \\
\text { Meloxicam } \\
7.5 \text { mg }\end{array}$ & \\
\hline Age (year) & $60.24(5.69)$ & $58.10(6.32)$ & 0.26 \\
\hline Median & 59.00 & 60.00 & \\
\hline \multicolumn{4}{|l|}{ Gender: } \\
\hline Women & $19(90.5 \%)$ & $17(81.0 \%)$ & 0.38 \\
\hline \multicolumn{4}{|l|}{ OA degree } \\
\hline I & $9(42.9 \%)$ & $10(47.6 \%)$ & 0.88 \\
\hline$\|$ & $9(42.9 \%)$ & $9(42.9 \%)$ & \\
\hline III & $3(14.3 \%)$ & $2(9.5 \%)$ & \\
\hline IL-1 $\quad(p g / m l)$ & $4.01(0.46)$ & $4.03(0.45)$ & 0.82 \\
\hline IL-6 $\quad(p g / m l)$ & $5.17(5.97)$ & $4.25(4.53)$ & 0.58 \\
\hline TNF- $\alpha(p g / m l)$ & $27.06(5.66)$ & $25.92(6.79)$ & 0.56 \\
\hline $\mathrm{Hb} \quad(\mathrm{gr} / \mathrm{dl})$ & $13.13(1.01)$ & $13.40(0.96)$ & 0.43 \\
\hline Leukocyt $\left(/ \mathrm{mm}^{3}\right)$ & $6936.84(1816.35)$ & $6662.50(1209.34)$ & 0.61 \\
\hline Trombocyt $\left(x 1000 / \mathrm{mm}^{3}\right)$ & $279.26(50.96)$ & $271.38(49.72)$ & 0.65 \\
\hline AST (U/L) & $24.79(12.20)$ & $20.81(4.28)$ & 0.22 \\
\hline$A L T(U / L)$ & $24.05(14.40)$ & $18.00(6.30)$ & 0.13 \\
\hline Ureum (mg/dl) & $29.50(9.65)$ & $22.81(6.00)$ & 0.02 \\
\hline Creatinine (mg/dl) & $0.87(0.39)$ & $0.77(0.17)$ & 0.35 \\
\hline $\mathrm{BMI}$ & $24.70(3.72)$ & $24.44(3.20)$ & 0.81 \\
\hline
\end{tabular}

Inflammatory markers in patients who participated in the study were on average above normal limits levels, IL-1 with a mean of $4.05 \mathrm{pg} / \mathrm{ml}$ (SD 0.45), IL-6 with a mean of $4.72 \mathrm{pg} / \mathrm{ml}$ (SD 5.28) and TNF- $\alpha$ with a mean of $26.50 \mathrm{pg} / \mathrm{ml}$ (SD 6.19). Other laboratory test like haematological liver and kidney function are also within normal limits. Average of BMI were slightly higher with a mean 24.57 (SD 3.43) showed excessive load on the joints, which that is one of risk factor for OA. Table 1 shows there is no statistically significant difference between the groups of patients who get Mahkota Dewa fruit extract $330 \mathrm{mg}$ compared with a control group who received $7.5 \mathrm{mg}$ meloxicam, so the research results obtained to avoid bias due to sample selection are not the same set of characteristics. However ureum level is significantly different, where the group Mahkota Dewa fruit extract $330 \mathrm{mg}$ had higher level with mean $29.50 \mathrm{mg} / \mathrm{dl}$ (SD 9.65) compared to meloxicam 7.5 $\mathrm{mg}, 22.81 \mathrm{mg} / \mathrm{dl}(\mathrm{SD} 6.00)(\mathrm{p}=0.02)$, although the levels are still within normal limits.

The data distribution was normally distributed on VAS and Lequesne index group analyzed by using parametric statistics. Reduction in VAS data $(\mathrm{p}=0.009)$ were not normally distributed, and the data is non-parametric, analyzed by the Wilcoxon test.

Table 2 Efficacy test after Mahkota Dewa fruit extract
(Phaleria macrocarpa fructus) $330 \mathrm{mg}$ treatment compared to meloxicam $7.5 \mathrm{mg}$ at day 14

\begin{tabular}{|c|c|c|c|}
\hline \multirow[b]{2}{*}{ Variable } & \multicolumn{3}{|c|}{ Day 14} \\
\hline & $\begin{array}{l}\text { Phaleria macro- } \\
\text { carpa } 330 \mathrm{mg} \\
\mathrm{N}=19 \\
\text { Mean (SD) }\end{array}$ & $\begin{array}{l}\text { Meloxicam } 7.5 \mathrm{mg} \\
\mathrm{N}=17 \\
\text { Mean (SD) }\end{array}$ & $P$ value \\
\hline \multicolumn{4}{|l|}{ VAS } \\
\hline Before & 40.48 (15.65) & $36.75(13.21)$ & 0.42 \\
\hline After & $24.47(10.66)$ & 19.71 (10.07) & 0.18 \\
\hline Decrease & $15.52(10.39)$ & $16.47(10.42)$ & 0.78 \\
\hline Lequesne & & & \\
\hline Before & $7.45(2.87)$ & $6.85(2.32)$ & 0.47 \\
\hline After & $4.71(2.58)$ & 3.77 (1.73) & 0.21 \\
\hline $\begin{array}{l}\text { Decrease } \\
\text { IL-1 (pg/ml) }\end{array}$ & $2.55(1.94)$ & $3.03(2.31)$ & 0.51 \\
\hline Before & $4.07(0.46)$ & $4.04(0.45)$ & 0.82 \\
\hline After & $4.13(0.63)$ & $3.98(0.41)$ & 0.39 \\
\hline $\begin{array}{l}\text { Decrease } \\
\text { IL-6 (pg/ml) }\end{array}$ & $-0.06(0.54)$ & $-0.01(0.25)$ & 0.72 \\
\hline Before & $5.17(5.97)$ & $4.25(4.53)$ & 0.58 \\
\hline After & $6.26(9.47)$ & $4.42(5.26)$ & 0.48 \\
\hline $\begin{array}{l}\text { Decrease } \\
\text { TNF- } \alpha \text { (pg/ml) }\end{array}$ & $-1.31(8.16)$ & $0.19(5.88)$ & 0.53 \\
\hline Before & $27.02(5.66)$ & 25.91 (6.79) & 0.56 \\
\hline After & $27.32(3.99)$ & $27.88(7.01)$ & 0.77 \\
\hline Decrease & $-0.26(4.72)$ & $-2.99(3.86)$ & 0.07 \\
\hline
\end{tabular}

Table 2 shows that the mean VAS decrease after 14 days of Mahkota Dewa fruit extract $330 \mathrm{mg}$ treatment was 15.52 (SD 10.39) did not differ significantly with meloxicam 7.5 mg 16.47 ( SD 10.42) $(\mathrm{p}=0.78)$. The VAS mean decrease $>20 \%$ so that it can be considered a significant reduction in the degree of pain. The mean decrease in Lequesne index after 14 days Mahkota Dewa fruit extract $330 \mathrm{mg}$ was 2.55 (SD 1.94) did not differ significantly with meloxicam $7.5 \mathrm{mg}$, 3.03 (SD 2.31$)(\mathrm{p}=0.51)$. Mahkota Dewa fruit extract 330 $\mathrm{mg}$ equivalent to $7.5 \mathrm{mg}$ of meloxicam in reducing the degree of pain as measured by VAS and Lequesne Index. The effect of decreasing the proinflammatory cytokine in the blood are IL $-1-0.06 \mathrm{pg} / \mathrm{ml}$ (SD 0.54) compared to $-0.01 \mathrm{pg} / \mathrm{ml}$ (SD 0,25 ) ( $\mathrm{p}=0.72), \mathrm{IL}-6-1.31 \mathrm{pg} / \mathrm{ml}(\mathrm{SD} 8.16)$ compared to 0.19 $\mathrm{pg} / \mathrm{ml}(\mathrm{SD} 5.88)(\mathrm{p}=0.53)$ and TNF- $\alpha-0.26 \mathrm{pg} / \mathrm{ml}(\mathrm{SD} 4.72)$ compared to $-2.99 \mathrm{pg} / \mathrm{ml}(\mathrm{SD} 3.86)(\mathrm{p}=0.07)$.

Table 3 Efficacy test after Mahkota Dewa fruit extract (Phaleria macrocarpa fructus) $330 \mathrm{mg}$ treatment compared to meloxicam $7.5 \mathrm{mg}$ at day 28

\begin{tabular}{lccc}
\hline \multirow{2}{*}{ Variable } & \multicolumn{3}{c}{ Day 28 } \\
\cline { 2 - 4 } & $\begin{array}{c}\text { Phaleria macro- } \\
\text { carpa 330 } \mathrm{mg} \\
\mathrm{N}=19\end{array}$ & $\begin{array}{c}\text { Meloxicam 7.5 mg } \\
\mathrm{N}=17 \\
\mathrm{Mean}(\mathrm{SD})\end{array}$ & P value \\
& Mean (SD) & & \\
\hline VAS & & & \\
Day 28 & $22.37(11.35)$ & $18.35(9.51)$ & 0.26 \\
Decrease & $17.63(10.05)$ & $17.82(7.97)$ & 0.95 \\
Lequesne & & & \\
Day 28 & $3.97(2.07)$ & $3.41(2.35)$ & 0.45 \\
Decrease & $3.29(2.45)$ & $3.38(1.68)$ & 0.89 \\
\hline
\end{tabular}


to 28 days in the group of Mahkota Dewa fruit extract $330 \mathrm{mg}$ amounted to 17.63 (SD 10.05) did not differ significantly with meloxicam $7.5 \mathrm{mg} 17.82(\mathrm{SD} 7.97)(\mathrm{p}=0.95)$, it also in the Lequesne index to 28 days in the group Mahkota Dewa fruit extract $330 \mathrm{mg}$ mean decrease of 3.29 (SD 2.45) did not differ significantly with meloxicam $7.5 \mathrm{mg}$ of 3.38 (SD 1.68) (p = 0.89). Mahkota Dewa fruit extract $330 \mathrm{mg}$ is still giving the effect of lowering the degree of pain on day 28 of observation, despite being dismissed for 14 days.

Side effect of NSAIDs are gastrointestinal symptoms such as nausea $5.9 \%(\mathrm{p}=0.28)$ and heartburn $23.5 \%(\mathrm{p}=0.03)$, and cause some subjects were excluded from the analysis, while Mahkota Dewa the fruit extract have no any complaint. In a safety testing show that Mahkota Dewa fruit extract 330 $\mathrm{mg}$ is safe for consumption, because it does not interfere with liver function, renal function and hematology, and also blood pressure after taking the test material for 14 days.

After Mahkota Dewa fruit extract $330 \mathrm{mg}$ treatment suspended for 14 days or at day 28 observation, when compared to meloxicam $7.5 \mathrm{mg}$, there is side effect on liver function, kidney function, and haematology. After day 28 observations, $\mathrm{Hb}$ of the subjects received $7.5 \mathrm{mg}$ of meloxicam was decrease $0.47 \mathrm{~g} / \mathrm{dl}$ (SD 0.51) compared to the group Mahkota Dewa fruit extract $330 \mathrm{mg} 0.07 \mathrm{~g} / \mathrm{dl}(\mathrm{SD} 0.52)(\mathrm{p}=0.03)$

\section{Discussion}

The long term pain in osteoarthritis need medications to reduce pain, but with lower side effects. Some pain medications such as NSAIDs have side effects on the gastrointestinal and cardiovascular systems. ${ }^{45-48}$ The use of herbs that have analgesic effect, is an option because of its low side effects. Some of the herbs have been studied to treat OA and is currently developed. ${ }^{49-55}$

Mahkota dewa is a plant that is widely used by people as a traditional medicine to treat various conditions as antimicrobial, anti-hypertension, anti-diabetes, antiinflammatory and anti-cancer. These herbal drugs have other effects as an anti-oxidant that also may reduce pain in OA. ${ }^{23,24}$

In OA progression chondro process will be disrupted due to several components such as proinflammatory cytokines IL1 , IL-6, TNF- $\alpha$, metalloproteinase enzymes, and also the role of oxidative stress due to Reactive Oxygen Species (ROS). 56,57

Inflammation and cartilage degradation is one of the hypotheses of the pathogenesis of OA. Inflammation is caused by arachidonic acid metabolism and the role of various enzyme. While cartilage degradation is caused by an imbalance of proteases and protease inhibitors that leads to excessive degradation of cartilage matrix. ${ }^{2}$ Oxidative stress causes damage to mitochondria that plays a role in the aging process, apoptosis, impaired function and tissue degeneration. Oxygen free radicals can penetrate into the cartilage and chondrocyte cells in vitro, although the actual chondrocyte cells can remain alive in a state without oxygen under normal circumstances, because it does not contain blood vessels. Chondrocyte metabolism itself is done anaerobically. Mitochondrial function in chondrocyte cells thought to prevent free radicals into the chondrocyte cells. Free radicals are already entered into the chondrocyte itself will result in a decrease in the synthesis of extracellular matrix resulting in thinning of the joints and improve joint calcification resulting in the formation of osteophytes. It also will play a role in cell apoptosis of chondrocytes. Mitochondria have their own chromosome is a genetic component in cell metabolism. The presence of genetic mutations will lead to a more rapid degenerative diseases, which will accelerate the occurrence of $\mathrm{OA}$ at a younger age. ${ }^{56,57}$

Pain that occurs in OA caused by three things: the inflammatory, ischemic and oxidative stress. Super oxide (SO) as free radicals also have an influence on tissue damage joints and cause pain. Phaleria macrocarpa also known to have antioxidant effects, therefore, anti-pain mechanisms presumably through suppression of this free radical oxidation pathway. ${ }^{56,57}$

The degradation of matrix molecules is actually a part of the remodelling process in the growth, development and joint matrix turnover. The process is actually a physiological process, which is regulated by various cytokines, growth factors, and hormones that regulate the synthesis of proteinase inhibitors and thus are in a balanced state. Excessive proteolysis is a pathological process resulting from an imbalance between proteinases (MMPs) and inhibitors (TIMPs). If there is more matrix destruction, it will be a lot of fragments that have been unraveled as collagen, proteoglycans and calcium crystals, regardless of the synovium space, and cause inflammatory responses, the production of prostaglandins as the end result will be more and more so that the effect of pain will increase. Effects of prostaglandins alone which can lead to vasodilation of blood vessels, increase vascular permeability, cause pain with bradykinin potentiating effect, activating lymphocytes, platelet aggregation, bone resorption, and T-cell suppression. Bone resorption that occurs will cause fragments of calcium such as calcium pyrophosphate crystals, hidroxiapatit, and calcium phosphates went into the synovium. The degree of inflammatory response as a result of this study is usually mild. Pain occurs not only from the experience of OA joints, because the actual joint cartilage does not contain nerves and vessels, but pain can also come from tissue around the joints, such as tendinitis, bursitis, ischemic subchondral bone, muscle spasm, osteophytes, psychic, ligament disruption, and others. Therefore, the degree of pain reduction at Mahkota Dewa fruit extract $330 \mathrm{mg}$ apart due to anti-inflammatory effects may be caused by the effects of antioxidants, the effects of other active substances are not known and may also have the effect of plasebo..$^{58-60}$

This study showed no difference in inflammatory markers found in the serum of patients with OA who have given good treatment with Mahkota Dewa fruit extract 330 $\mathrm{mg}$ and Meloxicam $7.5 \mathrm{mg}$, although the degree of pain was reduced. The cause is probably due to the lack of high-dose or measurement of inflammatory markers IL-1, IL-6, TNF- $\alpha$ in OA should not be taken from the serum but directly from synovial fluid because there is no significant relationship between systemic inflammatory OA with local inflammation. 
In the Framingham cohort study, years between 1998-2005 in 1235 obtained subject there was no significant relationship between markers of inflammation in OA. ${ }^{17}$ Placebo only actually has the effect to reduce levels of pain that is quite effective in OA. ${ }^{30}$ In the other study found that the mean TNF- $\alpha$ and IL- $1 \beta$ levels were lower in chronic OA compared with acute OA ${ }^{40}$ This differs from the type of inflammatory rheumatic diseases such as rheumatoid arthritis else (RA) which can be found higher levels of TNF- $\alpha$, IL-6 and IL-1 in the serum. EULAR recommendations also provide nonpharmacological therapy in patients with a diagnosis of OA in addition to therapy with multiple drugs. ${ }^{61}$

Experimental research of traditional medicinal native plants in Indonesia, Mahkota Dewa fruit extract $330 \mathrm{mg}$ given for 14 days in patients with a diagnosis of osteoarthritis showed effects can reduce pain by measurement of pain by VAS and Lequesne index. Patients with OA more than 60 years of age who may have renal impairment and cardiovascular disorders when NSAIDs treatment would be very dangerous can be given this treatment. Mahkota Dewa fruit extract is an therapeutic option for OA to reduce the degree of pain yet safe for the elderly.

The incidence of side effects of Mahkota Dewa fruit extract $330 \mathrm{mg}$ against haematological, liver function, kidney function, or the blood pressure in the observation of the day 14 and 28 are not found. This shows that the mahkota of dewa fruit extract is quite safe. LD50 Mahkota dewa extract in mice is greater than $1500 \mathrm{mg} / \mathrm{kg}$ bw. There were no significant differences between the groups in toxicity in experimental animals given the extract preparations Mahkota Dewa than the control group. ${ }^{19}$

On day 28 observations obtained significant reduction in Hb subjects who received $7.5 \mathrm{mg}$ of meloxicam for 14 days was $0.47 \mathrm{~g} / \mathrm{dl}$ (SD 0.51), this shows the long-term administration of NSAIDs for more than 14 days can lead to a decrease $\mathrm{Hb}$ due to hidden gastrointestinal bleeding in a person over the age of 60 years as the average age of the study subjects.

Limitation of this study are time of this study was conducted with only a two-week observation period where as in studies using herbs, the new effect can be seen in a longer time around more than three weeks. Measurement of proinflammatory markers IL-1, IL- 6 and TNF- $\alpha$ in two weeks has not been able to show a decrease in the blood levels, because the clinical symptoms will disappear earlier than the marker. In OA difficult to find increased inflammatory markers in the blood, but in the synovial fluid it can be higher than in the blood so that the examination in this study did not show significant results.

\section{Conclusion}

The conclusion of this study is Mahkota Dewa fruit extract (Phaleria macrocarpa fructus) $330 \mathrm{mg}$ reduces the degree of pain in OA patients as same as meloxicam $7.5 \mathrm{mg}$. Mahkota Dewa fruit extract $330 \mathrm{mg}$ does not reduce levels of IL-1, IL6 , TNF- $\alpha$ in patients with OA as well as the administration of meloxicam $7.5 \mathrm{mg}$. Mahkota Dewa fruit extract $330 \mathrm{mg}$ does not impair kidney function, liver function and haematologic parameters in patients with OA. Further research needs to be done about the content of some active substances Phaleria macrocarpa which acts as both an anti-inflammatory, and other effects that may influence the degree of pain decrease. Further research need to do to find the effects of Phaleria macrocarpa on levels of IL-1, IL- 6 and TNF- $\alpha$ in the synovial tissue or joint fluid in different doses.

\section{References}

1. Symmons D, Mathers C, Pfleger B. Global Burden of Osteoathritis in the Year 2000. WHO: Geneva; 2000.

2. Aigner T, Schmitz N. Pathogenesis and Pathology of Osteoarthritis. In: Hochberg MC, Silman AJ, Smolen JS, Weinbaltt ME, Weisman MH, editors. Rheumatology. 5th ed. MoSBy Elsevier: Philadelphia; 2011. P.1741-60

3. WHO Scientific Group. The burden of musculoskeletal condition at the start of the new millennium: WHO Technical Report Series. Geneva: WHO; 2010

4. Lawrence RC, Helmick CG, Arnett FC, Deyo RA, Felson DT, Giannini EH, et al. Estimates of the prevalence of arthritis and selected musculoskeletal disorders in the United States. Arthritis Rheum 1998;41:778-99

5. Kopec JA, Rahman MM, Berthelot JM, Petit CL, Aghajanian J, Sayre $\mathrm{EC}$, et al. Descriptive epidemiology of osteoarthritis in British Columbia, Canada. J Rheumatol 2007;34(2):386-93.

6. Dewi S, Wachjudi RG, Pramudiyo R. Profil Pasien di Klinik Reumatologi RS Dr. Hasan Sadikin Bandung tahun 2007: Temu Ilmiah Reumatologi. Jakarta; 2008

7. Hamik J, Rahmadi AR, Dewi S, Hamijoyo L, Wachjudi RG, Pramudiyo R. Profil Pasien Rawat Jalan di Klinik Reumatologi RSHS Bandung tahun 2011. Rematologi Klinik. Bandung; 2012.

8. Vidyaniati P, Pramudiyo R Prevalensi Penyakit Reumatik di Poliklinik Reumatologi RSHS Bulan Januari - Desember 2012: Temu IImiah Reumatologi. Jakarta; 2013

9. Sharm L. Epidemiology of osteoarthritis. In: Moskowitz R L, Howell DS, Setman DR, editors. Osteoarthritis diagnosis and medical/surgical management. 3rd ed. Philadelphia: WB Saunders; 2001. P.3-27

10. Centers for Disease Control and Prevention. Estimated number of US population with physician-diagnosed osteoarthritis, 1990. Atlanta: Center for Disease Control and Prevention; 1995.

11. Barr A, Conaghan PG. Osteoarthritis : a holistic approach. Clin Med (Lond) 2012;12(2):153-5.

12. Haq I, Murphy E, Darce J. Osteoarthritis. Postgrad Med J 2003;79:377383.

13. Altman RD. Clinical features of osteoarthritis. In: Hochberg MC, Silman AJ, Smolen JS, Weinbaltt ME, Weisman MH, editors. Rheumatology. 5th ed. MoSBy Elsevier: Philadelphia; 2011. P.1723-30.

14. Ausiello JC, Stafford RS. Trends in medication use for osteoarthritis treatment. J Rheumatol 2002;29:999-1005.

15. Tanna S. Osteoarthritis - opportunities to address pharmaceutical gaps: priority medicines for Europe and the world: A Public Health Approach to Innovation. 2004.

16. Dougados M, Hochberg MC. Management of Osteoarthritis. In: Hochberg MC, Silman AJ, Smolen JS, Weinbaltt ME, Weisman MH, editors. Rheumatology. 5th ed. MoSBy Elsevier: Philadelphia; 2011. P.1793-8.

17. Penninx BW, Abbas H, Ambrosius W, Nicklas BJ, Davis C, Messier SP, et al. Inflammatory markers and physical function among older adults with knee osteoarthritis. J Rheumatol 2004;31(10):2027-31.

18. Vlad SC, Neogi T, Aliabadi P, Fontes JDT, Felson DT. No association between Markers of Inflammation and Osteoarthritis of the Hands and Knees. J Rheumatol 2011;38(8):1665-70.

19. Ditjen POM. Inventaris Tanaman Obat Indonesia. 5th ed. Jakarta: Badan Penelitian dan Pengembangan Kesehatan Departemen Kesehatan Republik Indonesia; 1999. P.147-148. 
20. Harmanto N. Mahkota Dewa obat Pusaka Para Dewa. Jakarta: PT Agromedia Pustaka; 2002. P.7-21,27-9.

21. Nawawi A, Suwendar, Ana UH, Deden S. Antiinflammatory and analgesic effect of mahkota dewa [Phaleria macrocarpa (Sceff.) boerl fruit. In: 4th Malaysian Pharmaceutical Society Pharmacy Scientific Conference 2004. Kuala Lumpur: 2004.

22. Adnyana IK, Nawawi A, Fisheri N, Linda, Hayati. Antiarthritic effect of ethanol extract of Phaleria macrocarpa (Scheff.) boerl fruits on collageninduced arthritic rats. In: International Seminar on Pharmaceutics. Bandung: 2007.

23. Hakim RW. Elusidasi Struktur dan Uji Aktivitas Biologi Isolat Utama Buah Mahkota Dewa (Phaleria macrocarpa (Scheff.) Boerl. Bandung: Departemen Farmasi FMIPA ITB, 2004. P.7-22. Skripsi.

24. Mariani R. Telaah Kandungan Kimia dan Aktivitas Antiradang Buah Mahkota Dewa (Phaleria macrocarpa (Scheff.) Boerl.Bandung: Departemen Farmasi FMIPA ITB, 2005. P.29-30. Thesis.

25. Melori I. Uji Efek Antipirai Ekstrak Etanol Buah Mahkota Dewa (Phaleria macrocarpa (Scheff.) Boerl pada Tikus Jantan Galur Wistar. Bandung: Departemen Farmasi FMIPA ITB, 2006. P.4-6. Skripsi.

26. Oshimi, Shiori, et al. Studies on the constituents from the fruits of Phaleria macrocarpa. J Nat Med 2008:62(2):207-10. doi: 10.1007/s11418-0070209-9.

27. Zhang YB, Xu XJ, Liu HM. Chemical constituents from mahkota dewa. J Asian Nat Prod Res 2006;8(1-2):119-23.

28. Nelson AE, Jordan JM. Osteoarthritis: Epidemiology and Clasification. In: Hochberg MC, Silman AJ, Smolen JS, Weinbaltt ME, Weisman MH, editors. Rheumatology. 5th ed. Philadelphia: MoSBy Elsevier; 2011. P.1709-16

29. Croft P. The epidemiology of osteoarthritis : Manchester and beyond. Rheumatology (Oxford) 2005;44 Suppl 4, iv27-iv32.

30. Felson DT, Zhang Y. Local and systemic risk factor for incidence and prognosis of OA. In: Hochberg MC, Silman AJ, Smolen JS, Weinbaltt ME, Weisman MH, editors. Rheumatology. 5th ed. Philadelphia: MoSBy Elsevier; 2011. P.1717-22

31. Lauder SN, Carty SM, Carpenter CE, Hill RJ, Talamas F, Bondeson J, et al. Interleukin $1 \beta$ induced activation of nuclear factor- $\kappa b$ can be inhibited by novel pharmacological agents in osteoarthritis. Rheumatology (Oxford) 2007; $46(5): 752-8$

32. Williams RO, Mutafchieva LM, Feldmann M, Maini RN. Evaluation of TNF- $\alpha$ and IL-1 blockade in collagen induced arthritis and comparison with combined anti TNF- $\alpha$ / anti CD4 therapy. J Immunol 2000;165(12):7240-5.

33. Kagari T, Doi $H$, Shimozato T. The importance of IL-1 $\beta$ and TNF- $\alpha$ and the noninvolvement of IL-6, in the development of monoclonal antibodyinduced arthritis. J Immunol 2002;169(3):1459-66.

34. Joosten LAB, Helsen MMA, Saxne T, Van de Loo FAJ, Heinegard D, Van den Berg B. IL-1 $\beta$ blockade prevent cartilage and Bone Destruction in murine type II collagen induced arthritis, whereas TNF- $\alpha$ blockade only ameliorates joint inflammation. J Immunol 1999;163(9):5049-55.

35. Felson DT, Naimark A, Anderson J, Kazis L, Castelli W, Meenan RF. The prevalence of knee osteoarthritis in the elderly: The framingham osteoarthritis study. Arthritis Rheum 1987;30:914-18

36. Lewthwaire J, Blake S, Hardingham T, Foulkes R, Stephens S, Chaplin L, et al. Role of TNF- $\alpha$ in the induction of antigen induced arthritis in the rabbit and the anti-arthritic effect of species specific TNF- $\alpha$ neutralising monoclonal antibodies. Ann Rheum Dis 1995;54(5):366-74.

37. Lauder SN, Carty M, Carpenter CE, Hill RJ, Tahumas F, Bondeson J, Brennan $P$, et al. Interleukin $1 \beta$ induced activation of nuclear factor$\kappa b$ can be inhibited by novel pharmacological agents in osteoarthritis. Rheumatology 2007;46:752-8.

38. Wenham CYJ, Conaghan PG. The Role of Synovitis in Osteoarthritis. Ther Adv Musculoskel Dis 2010;6:349-59.

39. Beni MJ, Veale, Gerald OF, Van den Berg WB, Bresnihan B. Synovial tissue inflamation in early and late osteoarthritis. Ann Rheum Dis 2005;64:1263-7.

40. Benito MJ, Veale DJ, FitzGerald O, Van den Berg WB, Bresnihan B. Synovial tissue inflamation in early and late osteoarthritis. Ann Rheum Dis 2005;64:1263-7.
41. Roemer FW. Plain radiography and magnetic resonance imaging diagnostic in osteoarthritis: validated staging and scoring. J Bone Joint Surg Am 2009;91[Suppl 1]:54-62.

42. Altman R, Asch E, Bloch D, et al. Development of criteria for the classification and reporting of osteoarthritis. Clasification of osteoarthritis of the knee. Diagnostic and therapeutic criteria, committee of the American Rheumatism Association. Arthritis Rheum 1986;29:1039-49.

43. Von Korff M, Deyo RA, Cherkin D, Barlow SF. Back Pain in Primary Care. Spine 1993;855-62.

44. Lequesne MG, Mery C, Samson M, Gerard P. Indexes of severitry for osteoatrthritis of the hip and knee. Validation value in comparison with other assessment tests. Scan J Rheumatol 1987;65:85-9.

45. Rodrigues LAG, Hernandez-Diaz $S$. The risk of upper gastrointestinal complication associated with nonsteroidal anti-inflamatory drugs, glucocorticoids, acetaminophen, and combination of this agents. Artritis Res 2001;3:98-101.

46. Akhtar N, Haqqi TM. Current nutraceuticals in the management of osteoarthritis : a review. Ther Adv Musculoskelet Dis 2012;4(3):181-207.

47. Griffin MR, Ray WA, Schafener W. Nonsteroidal anti-inflamatory drug use and death from peptic ulcer in eldery person. Ann Intern Med 1988;109:359-63.

48. Fries JF, Williams CA, Bloch DA, Michel BA. Nonsteroidal anti-inflamatory drug-associated gastropathy incidence and risk factor models. Am J Med 1991:91:213-22.

49. Zohling J, Marc LM, Lapsley H, Cross M, Tribe M, Brooks P. Use of complementary medicines for osteoartrhritis: a prospective study. Ann Rheum Dis 2004;63:549-54.

50. MacLennan AH, Wilson DH, Taylor AW. Prevalence and cost of alternative medicine in Australia. Lancet 1996;347:569-73.

51. Ramsey SD, Spencer AC, Topolsky TD, Belza B, Patrick DL. Use of alternative therapies by older adults with osteoarthritis. Arth Care Res 2001;45:222-7.

52. Rao JK, Mihaliak K, Bradley J, Tierney WM, Weinberger M. Use of complementary therapies for arthritis among patients of rheumatologist. Ann Intern Med 1999;131:409-16.

53. Boisset M, Fitzcharles MA. Alternative medicine use by rheumatology patient in a universal health care setting. J Rheumatol 1993;21:148-52.

54. Guo R, Canter PH, Ernst E. A systematic review of randomized clinical trials of individualized herbal medicine in any indication. Postgrad Med $\mathrm{J}$ 2007:83:633-7.

55. Long L, Soeken R, Ernst E. Herbal medicines for the treatment of osteoarthritis: a systematic review. Rheumatology 2001;40: 779-93.

56. Canter PH, Wider B, Ernst E. The antioxidant vitamins A, C, E and Selenium in the treatment of arthritis: a systematic review of randomized clinical trial. Rheumatology 2007;46(8):1223-33.

57. Bae SC, Jung WJ, Lee EJ, Yu R, Sung MK. Effects of antioxidant supplements intervention on the level of plasma inflammatory molecules and disease severity of rheumatoid arthritis patients. J Am Coll Nutr 2009;1:56-62.

58. Stannus OP, Jones G, Blizzard L, Cicutinni FM, Ding C. Associations between serum levels of inflammatory markers and change in knee pain over 5 years in older adults: a prospective cohort study. Ann Rheum Dis 2013;72:535-40.

59. Pincus T, Koch G, Lei H, Mangal B, Sokka T, Moskowitz R, et al. Patients Preference for Placebo, Acetaminophen (paracetamol), or Celecoxib efficacy studies (PACES): two randomized, double blind, placebo controled, crossover clinical trial in patients with knee or hip osteoarthritis. Ann Rheum Dis 2004;63:931-39.

60. Zhang W, Robertson J, Jones AC, Dieppe PA, Doherty M. The placebo effect and its determinants in osteoarthritis: Meta analysis of randomized controled trial. Ann Rheumm Dis 2008;67:1716-23.

61. Fernandes L, Hagen KB, Bijlsma JWJ, Andreassen O, Christensen $P$, Conaghan PG, et al. EULAR recommendations for the nonpharmacological core management of hip and knee osteoarthritis. Ann Rheum Dis 2013;0:1-11. 